\title{
Meninos e meninas negras na literatura infantil brasileira: (des)velando preconceitos
}

\section{Eliane Debus*}

\section{Resumo}

O foco de reflexão deste texto recai sobre a leitura de livros de literatura de recepção infantil e sobre como eles tematizam as questôes étnico-raciais, a partir da caracterizaçáo das personagens, neste caso meninas e meninos. Os livros escolhidos para análise são Menina bonita do laço de fita, de Ana Maria Machado; Conceição de Vila Rica, de Joaquim Borges; Rufina, de Marciano Vasques; Minha família é colorida, de Georgina Martins; e Minhas contas, de Luiz Antonio. Além de trazerem crianças negras como personagens, as narrativas escolhidas se interligam pelo fato de essas mesmas personagens se encontrarem em espaços contemporâneos, representadas em suas atividades cotidianas. Com esta reflexáo, busca-se apontar as escorregadelas dos títulos, que, mesmo bem intencionados, apresentam um viés preconceituoso - (re)velando preconceitos, seja nas ilustraçôes, seja na caracterização das personagens; bem como em títulos que alcançam a alteridade - desvelando preconceitos.

Palavras-chave: Literatura infanto-juvenil. Racismo na literatura.

* Doutora em Letras (Teoria da Literatura) pela PUCRS. Professora do Departamento de Metodologia de Ensino, Centro de Educação, da Universidade Federal de Santa Catarina. 


\section{Onde se descreve a que se veio}

Fresquinho como água do pote, daqueles de barro em que nossos avós armazenavam água, foi o esboço deste texto, na época, ainda não coado, ainda náo filtrado, mas dado a beber aos convidados do encontro "Arte e Literatura na construção de conhecimentos étnico-raciais". ${ }^{1}$ Assim, este texto que agora se apresenta ao leitor carrega consigo as marcas do relido, do revisto, sem, no entanto, perder o viés lúdico que rodeava aquele momento, a saber: a estética como contributo para as relaçóes étnico-raciais.

Pesquisadora da literatura de recepção infantil e juvenil, nos últimos quatro anos, tenho me dedicado, de forma sistemática, a estudar os títulos disponíveis no mercado editorial brasileiro que apresentam, em suas páginas, a temática da cultura africana e afrobrasileira, com objetivo de mapear e dar visibilidade a essa produção, por acreditar que a literatura pode problematizar reflexóes sobre práticas antirracistas no universo da criança, seja no espaço escolar, seja em outros espaços.

A pesquisa sobre essa temática teve início em fevereiro 2006, com o desenvolvimento do projeto "A representação do negro na literatura brasileira para crianças e jovens: negação ou construção de uma identidade?” (DEBUS, 2006), que analisou sete catálogos editoriais referentes aos anos de 2005 e 2006. Do levantamento total de 1.785 títulos, 79 traziam personagens negras, destacando-se nestes uma recorrência aos (re)contos africanos por escritores brasileiros.

As informações oriundas do primeiro levantamento culminaram, no ano seguinte, com o projeto "As histórias de lá para leitores daqui: os (re) contos africanos para crianças pelas mãos de escritores brasileiros" (DEBUS, 2007), tendo como foco de análise os títulos de Rogério Andrade Barbosa, Joel Rufino dos Santos e Júlio Emílio Braz, autores que (re)contam narrativas da literatura oral africana e das literaturas afrobrasileiras, avaliando a importância dessas narrativas para a construçáo de uma identidade étnica.

Ambos os projetos foram desenvolvidos no âmbito do Programa de Incentivo à Pesquisa Docente (PUIP), promovido pela Universidade do Sul de Santa Catarina (Unisul), e tiveram seu primeiro edital divulgado em dezembro de 2005.

Em 2008/2009, retoma-se o primeiro mapeamento com o projeto: “A cultura africana e afrobrasileira na literatura de recepção infantil e juvenil: 
um diálogo singular em pluralidades", na orientação do trabalho de pesquisa da aluna de graduação do Curso de Pedagogia Margarida Cristina Vasques, por meio de uma bolsa Pibic, com o apoio do CNPq - Conselho Nacional de Desenvolvimento Científico e Tecnológico. A pesquisa é ampliada a partir da análise de três catálogos não visitados anteriormente, totalizando oito editoras. Foram, então, elencados um total de 2.416 títulos, e 171 apresentam o negro e/ou a cultura africana e afrobrasileira, correspondendo a $7 \%$ da publicaçáo das editoras analisadas. $\mathrm{O}$ trabalho culminou com as resenhas de 55 títulos.

Podemos dividir os títulos mapeados nessas pesquisas em cinco grandes blocos:

- a representação folclórica do negro;

- contos e recontos africanos;

- representação do negro no período escravocrata e pós-escravocrata;

- personagens (crianças e adultos) contemporâneas em situaçóes cotidianas; e

- narrativas de caráter informativo, embora estejam nos catálogos de literários.

Escolhemos como fio de tessitura para este texto o quarto bloco, isto é, aqueles títulos que apresentam, na sua construção narrativa, personagens negras contemporâneas, mais especificamente crianças, selecionando, para leitura, cinco títulos: Menina bonita do laço de fita (Ática, 1997), de Ana Maria Machado e ilustraçóes de Claudius; Conceição de Vila Rica (Paulinas, 2000), de Joaquim Borges e ilustrações de Denise Nascimento; Rufina (Franco, 2004), de Marciano Vasques e ilustraçóes de Osório Garcia; Minha familia é colorida (SM, 2005), de Georgina Martins e ilustraçôes de Maria Eugênia; e Minhas contas (Cosac Naify, 2008), de Luiz Antonio e ilustrações de Daniel Kondo.

Nossa reflexão busca apontar as escorregadelas dos títulos, que, mesmo bem intencionados, apresentam um viés preconceituoso - (re)velando preconceitos, seja nas ilustraçóes, seja na caracterização das personagens; bem como em títulos que alcançam a alteridade na representação do Outro - desvelando preconceitos. 


\section{Dos livros e das leituras}

A literatura infantil e juvenil, como produção cultural que tem seu foco na linguagem, obedece a critérios esteticamente literários. Entendida dessa forma, compreende-se que essa produção não é a prima pobre de uma literatura rica, por isso não tem sustentação desqualificar uma em detrimento da outra. Como afirma Antonio Candido (1988), “[...] o subsolo da arte é um só" ou, ainda, nas palavras de Cecília Meireles (1984), “[...] tudo é uma arte só".

O que ocorre é que o atrelamento histórico a um público leitor específico - a criança - fez com que essa literatura fosse se transformando, ao longo do tempo, na mesma proporçáo em que se altera a imagem social de infância. Também é necessário dizer que as transformaçôes paulatinas, no tratamento dado à palavra e aos temas, fizeram com que os títulos para crianças e jovens conquistassem espaço editorial. Assim sendo, as reflexōes sobre essa produção, contemporaneamente, têm ganhado fôlego, e são muitos os vieses de pesquisas que tentam abarcar a sua confecção, circulação e consumo.

No entanto, seria imaturo dizer que o livro literário de recepção infantil não possui características específicas. Essas características se sobressaem, de imediato, no aspecto gráfico do livro: tamanho e formato do livro; capa e contracapa; tipo e tamanho da letra; tipo, qualidade e textura do papel; diálogo entre a mancha textual e a ilustração.

Dessas características elencadas, contemporaneamente, a ilustração tem papel intrínseco nas publicações e é lida também como narrativa, fato que ganha proporçóes maiores quando se trazem para a cena os livros de imagens. A relação entre o signo icônico e o verbal, nesse tipo de produção, é tão estreita que tem acompanhado os critérios de escolhas dos livros, como destacado em trabalhos recentes sobre a avaliação dos títulos que compóem os acervos literários das escolas públicas para as séries iniciais do Ensino Fundamental, por exemplo, o desenvolvido pelos avaliadores dos livros selecionados para compor o PNBE 2005 (ANDRADE; CORSINO, 2007).

Ciça Fittipaldi (2008) argumenta que a ilustração é linguagem e, como linguagem criativa, propicia ao leitor fruição estética e experimentação. Assim, as ilustraçôes de um livro infantil não devem ser mera reproduçấo do texto verbal; o diálogo tecido entre o texto verbal e o texto visual deve 
ultrapassar essa esfera. A boa ilustração talvez seja aquela que "[...] busque atravessar o verbal em sua referencialidade e estabelecer a partir dele uma leitura própria, propositiva, e criativa" (ANDRADE; CORSINO, 2007, p. 87). No entanto, a mesma ilustração que abre horizontes pode encarcerálos, na medida em que "[...] constroem enredos e cristalizam as percepçóes sobre o imaginado" (LIMA, 2005, p. 101).

O texto literário partilha com os leitores, independente da idade, valores de natureza social, cultural, histórica e/ou ideológica por ser ele uma realização da cultura e estar integrado num processo comunicativo. Porém, pelo potencial ficcional, “[...] esses valores são dados a ler de forma não explícita, através do jogo de negociação de sentidos estabelecido no diálogo leitor/texto" (AZEVEDO, 2006, p. 19).

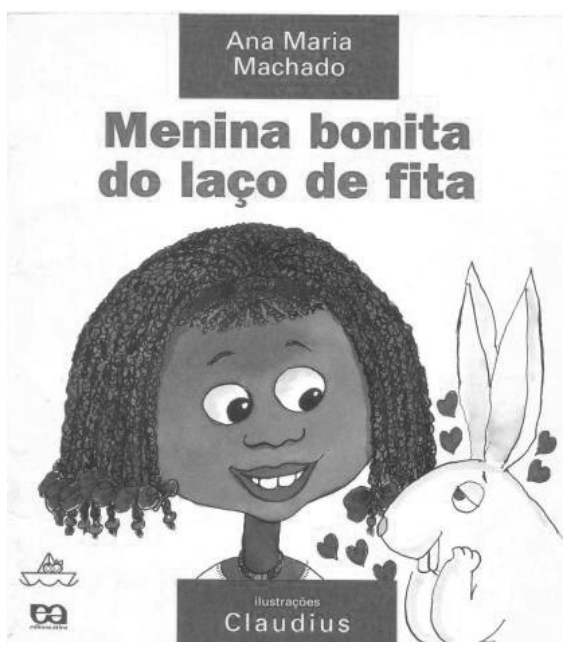

Figura 1: Menina bonita do laço de fita

Fonte: Editora Ática $(2000 ; 2010)$.

O livro Menina bonita do laço de fita, de Ana Maria Machado, talvez seja um dos títulos de literatura infantil mais conhecido entre os professores, e o mais utilizado em trabalhos com as crianças para discutir sobre identidade, autoestima, pertencimento, entre outros (para comprovar, basta visitarmos 
os sites de busca da internet e lá encontraremos várias imagens de trabalhos realizados com esse título em relação à questão étnico-racial); também é o de publicação mais antiga, entre os títulos aqui analisados.

Ana Maria Machado começa a escrever para o público infantil na década de 1970 e nesses 40 anos de profissão já publicou mais de 100 títulos, traduzidos para diversas línguas. Vale ressaltar dois feitos: em 2000 recebeu o prêmio Hans Christian Andersen e em 2001 assumiu a cadeira número 1 da Academia Brasileira de Letras.

O livro aqui analisado foi publicado na década de 1980 pela editora Melhoramentos, e atualmente é comercializado pela Ática. O enredo da narrativa se desenvolve em torno do conflito de identidade: um coelho branco "de orelha cor-de-rosa, olhos vermelhos e focinho nervoso" que almeja ser "preto" como sua vizinha, uma menina bonita do laço de fita.

O livro tem seus méritos, dentre os quais três podem ser destacados: o primeiro se refere à valorização de aspectos fenótipos, a descrição da menina é feita a partir de caracterizaçóes que colaboram com a autoestima da criança negra: "Os olhos dela pareciam duas azeitonas pretas, daquelas bem brilhantes. Os cabelos eram enroladinhos e bem negros, feito fiapos da noite. A pele era escura e lustrosa, que nem o pêlo da pantera negra quando pula na chuva" (MACHADO, 1997, s/p).

Embora a comparação dos olhos da menina com azeitonas negras possa parecer, em princípio, algo não usual, as outras inferências contribuem para levar o leitor a crer que é algo positivo.

O segundo mérito está centrado na reflexão sobre o desconhecimento da sua origem, a noção de pertencimento não existente por parte da personagem menina. Esse não-conhecimento de suas raízes faz com que ela, a cada indagação do coelho - "Menina bonita do laço de fita, qual teu segredo para ser tão pretinha" - crie fantasticamente motivos para o seu ser "preto".

A mente inventiva da menina leva o coelho a vivenciar experiências hilariantes, ao mesmo tempo em que frustrantes, na tentativa de se "pretear": tomar um banho de tinta preta, beber muito café preto e comer jabuticabas. O riso é provocado pelas situaçóes desastradas nas quais o coelho se envolve na tentativa de ser outro.

O terceiro ponto dialoga com o segundo e centra-se no reconhecimento da ancestralidade. Pela mão do adulto, a figura materna, a menina é levada a 
(re)conhecer a sua origem por meio de um álbum de fotografia da família. Embora outras leituras apontem esse diálogo como preconceituoso, ao afirmar que "artes de uma avó preta que ela tinha..." como uma expressão negativa (OLIVEIRA, 2003), observa-se que a compreensão do coelho sobre o que é dito não se faz negativo: "Aí o coelho - que era bobinho, mas nem tanto - viu que a mãe da menina devia estar dizendo a verdade, porque a gente se parece sempre é com os pais, os tios, os avós e até com os parentes tortos".

No entanto, algumas questóes devem ser levantadas: a discussão sobre o ser negro é mediado pela cor. A menina não é descrita como negra e sim "preta"; ao apresentar a figura materna, esta é descrita como uma bela mulata, termo que carrega toda uma carga pejorativa, já criticado em trabalhos anteriores (SILVA, 2001; OLIVEIRA, 2003); o conflito étnicoracial se constrói pela inversão dos papéis, a menina negra não é rejeitada, e sim outro - mesmo que animal - quer ter as características iguais às dela para ser "bonito".

As ilustraçóes da publicação, pela editora Melhoramentos, na década de 1980, receberam severas críticas, sendo consideradas por estudiosos (SILVA, 2001; OLIVEIRA, 2003) eivadas de estereótipos, em especial a caracterização animalizada da menina, contradizendo o texto que elogiava o fenótipo negro. Por outro lado, a ilustração de Claudius, para a editora Ática, tem recebido elogios.

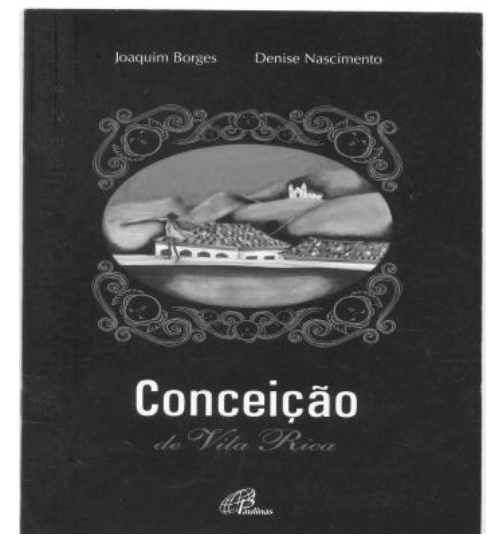

Figura 2: Conceição, uma menina "bem moreninha"

Fonte: Paulinas (2007-2010). 
O livro Conceição de Vila Rica, de Joaquim Borges, apresenta várias contradiçóes, que não podem ser entendidas como sendo das personagens, e sim da própria construção da escrita. Em atividades realizadas com professores $^{2}$, constatou-se que este livro impressiona à primeira vista, principalmente pelo fato de os conflitos ocorrerem no espaço escolar e, nesse mesmo espaço, serem resolvidos. No entanto, faz-se imprescindível que estejamos atentos a como esses conflitos são abordados. Eles são, afinal, resolvidos ou silenciados?

A narrativa se desenvolve em torno dos conflitos étnico-raciais vividos pela menina Conceição, ou melhor, Cafuringa, apelido pejorativo que recebe das crianças de sua turma na escola, devido ao seu cabelo "crespo, puxado, quase espetado".

A menina "bem moreninha" entende o apelido como prova de carinho e é "tolerante" com as outras crianças, "não se importou muito com o novo nome", porém, em casa, ela fica "calada e tristinha”, levando a mãe a concluir que o motivo é o apelido.

A solução do conflito se efetiva por meio de um ato heróico da mãe da menina. Um garoto da escola, justamente aquele que mais "agredia" Conceição, sofre um acidente, e quem o acompanha até o hospital e doa o sangue necessário para salvar a sua vida é a mãe dela.

Somente a partir desse evento é que a professora intervém na relação conflituosa entre as crianças, explicando que o nome da menina é Conceição e assim ela deve ser tratada. A menina agora é aceita pelo grupo, no entanto, não pelas suas qualidades específicas, mas pelo heroísmo materno, pois, na escola:

No outro dia a menina moreninha chegou à porta da escola e quase todos os colegas vieram abraçá-la. Só depois de muito lero-lero é que ela ficou sabendo que o acidentado que sua máe ajudou a salvar era o Junin, dos olhos azuis, da classe dos fundos (BORGES, $2000, \mathrm{~s} / \mathrm{p})$.

Se a atuação da professora não foi decisiva, ela colaborou para o novo relacionamento entre a turma, quando apresentou a reproduçáo de duas pinturas do Mestre Athayde, no teto da igreja de São Francisco de Assis e na igreja de Santa Ifigênia, em Ouro Preto, Minas Gerais. Ao 
destacar que o artista retratou uma santa mulata no centro da pintura, envolveu a turma, aguçando sua curiosidade pelo tema, levando as crianças a refletirem sobre como o negro está inserido em nossa história e cultura, sobre a importância de suas expressóes e vivências. No entanto, a história de Conceição, "Çãozinha", se enreda com a dos artistas, via histórico de seus ancestrais, construtores e artistas, tendo ela uma "herança artística" da qual não se vangloria.

Constata-se, assim, que as diferenças são equalizadas na narrativa pelo ato heróico da mãe e pela herança artística da menina, que possui ancestrais vinculados aos grandes artistas mineiros. Outro fato que precisa ser anunciado é a descrição da menina, a qual, do início ao fim da narrativa, é apresentada como "moreninha", terminologia que se enquadra no que Souza (2005) denomina "pacto de convivência”, por conferir ao imaginário social "uma posição mais sociável ao sujeito" e mascarar a identidade negra, colaborando mais para a discriminação racial do que para a promoção da igualdade étnico-racial.

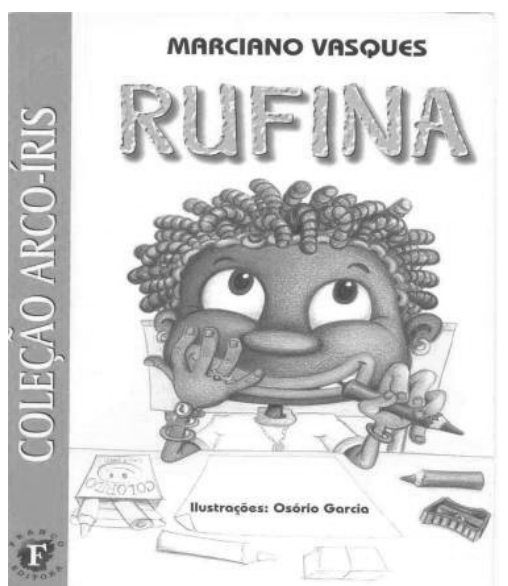

Figura 3: A fada negra de Rufina: o conflito resolvido pela professora Fonte: Franco... (2007).

O livro de Marciano Vasques apresenta uma narrativa que tem como protagonista Rufina, uma menina que gosta de ir à escola e lá fazer três coisas que são muito caras: ouvir histórias, desenhar e pintar. E é a partir 
da realização interligada dessas três atividades que o enredo da narrativa é desenvolvido, bem como é de onde nasce o conflito.

A professora narra um conto de fadas e propóe que as crianças desenhem e pintem a narrativa a partir do que ouviram. Histórias de fadas são apreciadas pela menina que sabe, pela voz materna, que "Toda menina tem uma fada que a protege", e assim, entusiasmada, começa a desenhar.

A menina, bem como seus colegas, termina o desenho, e todos são convidados a afixá-los num varal montado na sala de aula. A menina se encolhe receosa quando vê a produção de seus colegas e se nega a colocar a sua. O que ela via? "Fadas loiras, olhos azuis, outras com cabelos negros e olhos verdes, varinha de condão, longos mantos, não faltou nada. A criança pôs no papel toda sua criatividade" (VASQUES, 2004, p. 8).

Convencida pela professora, a menina, durante o recreio, coloca o desenho no varal. Assim, quando as crianças retornam começam, em grupo de cinco, uma visita à exposição. Até que um menino encontra o desenho de Rufina e cai na gargalhada, seguido de outros discursos ofensivos: "Não existe fada preta! - berrou um menino. - É mesmo! Não existe fada negra. Só se for na África! - falou uma menina” (VASQUES, 2004, p. 13).

A professora chama a turma para uma conversa e aponta as qualidades no desenho da menina: "lindo e caprichado" como tudo que ela fazia; pergunta se o motivo da graça estava na palavra África e termina questionando como o grupo sabe que as fadas são brancas e loiras: "Mas a fada dela é diferente!" é a resposta que surge. Diante disso, a professora destaca a originalidade do desenho e felicita a diferença.

A professora segreda à menina que ela não precisava ter usado o lápis marrom e sim o preto, pois era esta a cor da sua fada. Diante desse apoio, a menina sente um "contentamento danado": "A professora estava certa. A sua fada era negra. Uma fada pretinha, igual a ela, e não precisava ficar envergonhada por isso" (VASQUES, 2004, p. 15).

Se o discurso narrativo apresenta ao leitor uma voz em consonância com o respeito às diferenças, as ilustraçóes destoam, em especial, a imagem de Rufina.

A escritora carioca Georgina Martins inicia sua produção literária para o público infantil e juvenil em 1999, e seus livros revelam a importância de viver em sociedade com valores de solidariedade e respeito 
ao Outro. Nas propostas de sua obra, encontramos espaços para reflexão sobre a pluralidade cultural e a alteridade diante do Outro, como nos títulos Uma maré de desejos (Ática); No olho da rua - historinhas quase tristes (Ática); $O$ menino que brincava de ser (DCL); O menino que não se chamava João e a menina que não se chamava Maria (DCL); Com quem será que eu me pareço? (Planeta); Diário de um lobisomem (DCL); e Minha familia é colorida (SM).

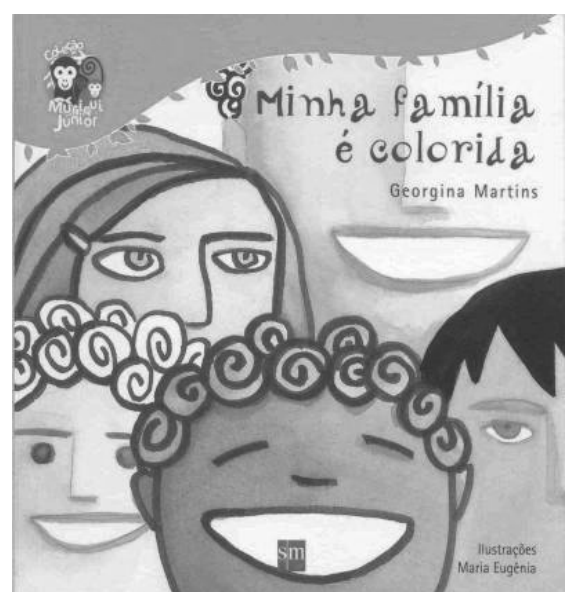

Figura 4: Ângelo, um menino de muitas cores Fonte: Supermercado... (2010).

Em seu livro Minha família é colorida ${ }^{3}$, a autora dialoga sobre o complexo universo da pluralidade étnico-racial presente nas famílias brasileiras. Através do diálogo entre a figura materna e o menino Ângelo, a história dos seus antepassados vai sendo revelada numa palheta multicor.

Ângelo, “[...] um menino que gosta muito de pensar nas coisas da vida”, observando sua família, pergunta à mãe por que seu cabelo não "vua”, e o cabelo da avó "vua". Ao questionamento, o menino emenda uma resposta dizendo que o pai, também de cabelo que não "vua", passou cola no cabelo dos dois. A mãe faz-se desentendida, apenas o corrige dizendo-lhe que "não é vua que se fala, é voa!".

Ângelo continua a indagar sobre a diferença entre seu cabelo e a cor de sua pele em relação aos outros membros da família. "Mãe, eu sou negro?". 
É essa pergunta, feita pelo menino, que desencadeia toda a narrativa da mãe sobre a história genealógica da família, explicando-lhe por que ele é um menino "moreno". Contextualiza a sua origem a partir do momento em que seus bisavós se conheceram (a união da bisavó negra com o bisavô branco) até a formação atual da família, com diferentes cores e modos, ou seja, uns de cabelos lisos, outros de cabelos encaracolados; uns de olhos claros, outros escuros.

O texto explora as diferentes estéticas herdadas pela união de pessoas de naçôes distintas e lugares distantes. A mãe conta a história de forma simples, comparando a cor de pele negra com a noite; os olhos pretinhos como duas jabuticabas; os olhos azuis com o céu; a pele branca com o copo de leite. Por fim, o menino Ângelo identifica as diferenças e particularidades suas e da família com sua caixa de lápis de cor, afinal, ambos são coloridos.

O trabalho de ilustração de Maria Eugênia dialoga com a narrativa, desenhando a fisionomia dos personagens de forma lúdica e alegre. A bisavó de Ângelo é pintada com cor preta, enquanto seus descentes compartilham de tons alaranjados ao branco, tornando visível, ao pequeno leitor, as diferenças físicas apontadas pelo enredo. Ao final, no último parágrafo, o menino Ângelo justifica as diferenças: "É porque a nossa família é toda colorida, e eu acho que ela é muito bonita, igualzinha à minha caixa de lápis de cor!”. Logo a seguir, estão desenhados os lápis de cor marrom, laranja, verde, amarelo e vermelho.

O texto trabalha a miscigenação das diferentes etnias, porém, embora a nossa formação histórica seja caracterizada pela miscigenação étnica, racial e cultural, faz-se necessário um olhar cuidadoso e atento ao nos aproximarmos dessa questáo. $\mathrm{O}$ contexto histórico, que envolve essa característica nacional, origina-se da dominação e da exploração do trabalho escravo. A ideia de nação mestiça, no Brasil, é resultado de um processo colonizador violento, e não apenas da relação amistosa entre as raças. Como destaca Gomes (2005), a partir da reflexão sobre Casa-grande e senzala, de Gilberto Freyre,

Não há como admitir que uma sociedade em que as relaçôes entre diferentes grupos étnico-raciais foram construídas/pautadas no trabalho escravo, na 
dominação e na exploração possa se sentir orgulhosa da forma como, historicamente, se deu o seu processo de mestiçagem. (GOMES, 2005, p. 59).

Assim, a narrativa, por meio de uma visão ingênua e romântica, pode remeter o leitor (mesmo o pequeno leitor) ao falso conhecimento acerca da historicidade sobre o processo de mestiçagem do nosso país.

No início do texto, o menino Ângelo pergunta à mãe se era negro, mas, embora a ilustradora Maria Eugênia o tenha desenhado com traços africanos, a mãe faz uso da expressão "bem moreno" no contexto da resposta. O uso de tal termo, característica de um vocábulo permeado pelo preconceito, traz, mesmo que de forma ingênua, marcas de discriminação, já encontradas na descrição da menina no livro Conceição de Vila Rica.

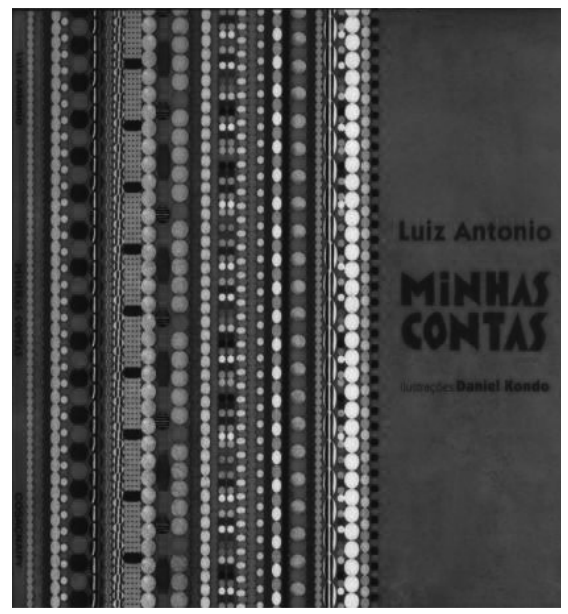

Figura 5: As contas do menino Nei

Fonte: Cosac Naif (1997).

O conflito religioso é o tema que circunda o livro Minhas contas, de Luiz Antonio. Dois meninos, uma amizade intensa e a intransigência adulta que coloca em xeque a amizade dos pequenos.

Narrado em primeira pessoa pelo menino Nei, que se vê impedido de brincar com o melhor amigo, Pedro, por causa de suas contas, quando a mãe deste solicita: "Pedro, meu filho, não quero mais você com o Nei. Ele 
usa aquelas coisas no pescoço [...] Coisa de macumbeiro. Tá proibido de entrar aqui em casa!" (ANTONIO, 2008, s/p).

O colar de contas, poderíamos aqui metaforizar como que o cordão umbilical que une o menino Nei ao candomblé, é o objeto que identifica a sua religiosidade, que, ao mesmo tempo, cria a fronteira e divide a amizade. A dor da separação faz o pequeno Nei sentir muita raiva e se perguntar pela validade e importância de sua religião: "E se a mãe dele estiver certa?".

As figuras femininas da avó e da mãe levam o menino a pensar nas raízes religiosas do povo negro e a não rejeitar essas raízes. A avó recupera para o menino a história de seus antepassados e dos enfrentamentos para preservar a sua cultura e religião, retoma cenas de perseguição ao candomblé e coloca para o menino que a liberdade religiosa é essencial:

\author{
Seu avô era católico, \\ Não ia no terreiro. Todo \\ Mundo tem o direito \\ De ter a sua religião. \\ De usar um crucifixo, \\ Um quipá, um turbante, \\ Um manto colorido, \\ Guias ou fio de contas. (ANTONIO, 2008, s/p)
}

O auxílio da avó de Nei, que com ervas cura a mãe de Pedro de uma coceira, faz com que o respeito às crenças se instaure e possibilita o reencontro dos dois meninos.

O diálogo entre linguagem verbal e linguagem visual se estreita e ganha vida nas ilustraçóes de Daniel Kondo, que escolheu as cores do candomblé para ilustrar seu livro. No paratexto que acompanha o livro, somos apresentados a 18 orixás do candomblé, os quais Kondo introduz de forma sutil nas ilustraçóes ora por meio de objetos, ora por meio das cores.

Esse livro traz, com maestria, uma temática de cunho íntimo e familiar que é a religiosidade, nesse caso, a herança religiosa do povo negro, quase inexistente nos livros para crianças, culminando com uma valorização da religiáo de matriz africana, rompendo com um discurso homogêneo, e muitas vezes imposto, sobre religiosidade. Como destaca Ana Célia Silva, "A imposição de uma só matriz religiosa constitui-se em violência simbólica contra os grupos subordinados, que náo têm poder para colocar 
seus conteúdos e significados culturais nos currículos de ensino de nossas escolas" (SILVA, 2005, p. 29).

\section{Onde se unem os fios das narrativas e se tecem as considerações}

Os cinco títulos escolhidos para esta leitura tematizam o conflito étnico-racial, isto é, entra em cena na narrativa o enfrentamento das personagens crianças diante da condição negra em uma sociedade que, historicamente, privilegiou a condição branca. Seria esta a forma mais interessante de apresentar aos leitores as personagens negras, pelos conflitos étnico-raciais?

Embora essa não seja a única possibilidade de apresentação - é necessário salientar que, atualmente, alguns livros infantis (re)apresentam personagens negras por meio da ilustração, sem que no texto apareçam registrados enfrentamentos étnico-raciais, como é o caso de $O$ menino Nito... então homem chora ou não?, de Sonia Rosa; ou Ana e Ana, de Célia Godoy -, acreditamos que narrativas que apresentam o enfrentamento também são necessárias, até porque, verossímeis.

O espaço escolar é um local de embate, onde o preconceito impera, por vezes, de forma sutil - como a professora que se refere à Conceição como "moreninha", do início ao fim da narrativa -, outras vezes, de forma aviltante e cruel por meio da ridicularização e humilhação das pesonagens, como ocorreu com Conceição e Rufina.

Aspectos da construção física das personagens, como os cabelos, estão presentes em quatro narrativas. Nos títulos Menina bonita do laço de fita e Rufina, o cabelo trançado é descrito como algo bonito; em ambos, aparecem as mães na tarefa de confeccionar as tranças. Já os cabelos de Ângelo e Conceição são aspectos que os levam a indagaçôes: o primeiro, no sentido de saber por que eles não "vuam", retomando um discurso de vínculos parentais; enquanto a menina deve ao cabelo "ruim" o apelido de Cafuringa.

Nas cinco narrativas, a mediação do adulto é fator determinante para o desenlace, lembrando que, em todas, esse adulto é representado pela figura feminina: professora, mãe e/ou avó, não aparecendo, em nenhuma delas, a figura masculina. 
O livro literário de recepção infantil exige uma leitura múltipla de dois códigos que se entrelaçam: palavra e imagem. Assim, a ilustração também pode introduzir estereótipos, como os lábios animalescos de Rufina; ou apresentar uma complexidade que exige do leitor conhecimentos mais amplos, como as cores dos orixás presentes em Minhas contas.

Por fim, é necessário lembrar, como já destacamos em trabalho anterior, que:

[...] A obra literária exerce no leitor um "poder", seja negativo, seja positivo. No primeiro caso, ao trazer para o leitor personagens submissas, sem noção de pertencimento, desfiguradas de sua origem étnica, não há ampliação do seu repertório cultural, o que colabora para uma visão deturpada de si e do outro. Por outro lado, a identificação com personagens conscientes de seu papel social, de suas origens, e respeitosos diante da pluralidade cultural acena para uma relação de respeito ao outro. (DEBUS, 2007, p. 268)

Por isso e mais um pouco, faz-se crucial o debruçamento teórico sobre a produção literária de recepção infantil, pois, a partir dele, se levantam reflexôes, apontam-se questionamentos e, por que não, inviabiliza-se a circulação daqueles títulos que, imbuídos de preconceitos, colaboram para uma visão deturpada das relaçóes étnico-raciais; por outro lado, o texto nunca é neutro, e algumas contradiçóes e ambiguidades na sua estrutura servem também para promover contraargumentaçóes e (re)forçar um discurso que leve em conta a construção de uma sociedade plural.

\section{Notas}

1 Evento organizado pelo PET/Pedagogia e Programa de Pós-Graduação em Educação - CED/UFSC, em maio de 2009.

2 No ano de 2007, realizamos formação junto a aproximadamente 200 professores de cinco áreas diferentes: Língua Portuguesa, História/Geografia, Artes, Educação Física de $1^{\circ}$ ao $5^{\circ}$ Anos do Ensino Fundamental, da Rede Municipal de Ensino de Florianópolis, SC, totalizando 40 
horas de curso, socializando a pesquisa do PUIP 2006 e trabalhando com diversos livros infantis, entre eles Conceição de Vila Rica.

3 Este livro recebeu atenção no artigo "A linguagem literária e a pluralidade cultural: contribuições para uma reflexão étnico-racial na escola" (DEBUS; VASQUES, 2009).

\section{REFERÊNCIAS}

ANDRADE, Ludimila; CORSINO, Patricia. Critérios para a constituição de um acervo literário para as séries iniciais do Ensino Fundamental: o instrumento de avaliação do PNBE 2005. In: PAIVA, Aparecida et al. Literatura: saberes em movimento. Belo Horizonte: Ceale/Autêntica, 2007.

ANTONIO, Luiz. Minhas contas. Ilustraçóes de Daniel Kondo. São Paulo: Cosac Naify, 2008.

AZEVEDO, Fernando. Literatura infantil: recepção leitora e competência literária. In: . Lingua materna e literatura infantil: elementos nucleares para professores do ensino básico. Lisboa: Lidel, 2006. p. 19.

BORGES, Joaquim. Conceição de Vila Rica. Ilustração Denise Nascimento. São Paulo: Paulinas, 2000.

CANDIDO, Antonio. Sílvia Pelica na liberdade. In: LAJOLO, Marisa; ZILBERMAN, Regina. Um Brasil para crianças: para conhecer a literatura infantil brasileira. São Paulo: Global, 1988.

COSAC NAIF. São Paulo, 1997. Disponível em: <www. editoraCosacnaif.com.br>. Acesso em: 23 nov. 2009.

DEBUS, Eliane S. D. A representação do negro na literatura brasileira para crianças e jovens: negação ou construção de uma identidade? Florianópolis: Unisul, 2006. Relatório do Programa Unisul de Iniciação à Pesquisa (PUIP).

. As histórias de lá para leitores daqui: os (re)contos africanos para crianças pelas mãos de escritores brasileiros. 2007. Florianópolis: Unisul, 2007. Relatório Programa Unisul de Iniciação à Pesquisa (PUIP). 
DEBUS, Eliane S. D. A representação do negro na literatura para crianças e jovens: negação ou construção de uma identidade? In: AZEVEDO, Fernando (Coord.). Imaginário, identidades e margens: estudos em torno da literatura infanto-juvenil. Gaia, Po: Gailivro, 2007.

; VASQUES, Margarida Cristina. A linguagem literária e a pluralidade cultural: contribuiçóes para uma reflexão étnico-racial na escola. Conjectura: Filosofia e Educação, v. 14, n. 2, p. 133-144, maio/ ago. 2009.

EDITORA Ática. São Paulo: Abril Educação, 2000-2010.

FITTIPALDI, Ciça. O que é uma imagem narrativa? In: OLIVEIRA, Ieda de (org.). O que é qualidade em ilustração no livro infantil e juvenil: com a palavra o ilustrador. São Paulo: DCL, 2008.

FRANCO Editora. Juiz de Fora, MG, 2007. Disponível em: <www. francoeditora.com.br>. Acesso em: 17 nov. 2009.

GODOY, Célia. Ana e Ana. Ilustrações de Fê. São Paulo: DCL, 2003.

GOMES, Nilma Lino. Alguns termos e conceitos presentes no debate sobre relações raciais no Brasil: uma breve discussão. In: BRASIL. Ministério da Educação, Secretaria de Educação Continuada, Alfabetização e Diversidade. Educação anti-racista: caminhos abertos pela Lei Federal no 10.639/03. Brasília, 2005.

LIMA, Heloisa Pires. Personagens negros: um breve perfil na literatura infanto-juvenil. In: MUNANGA, Kabengele (Org.). Superando o racismo na escola. 2. ed. Brasília: Ministério da Educação, 2005.

MACHADO, Ana Maria. Menina bonita do laço de fita. Ilustrações de Claudius. São Paulo: Ática, 1997.

MARTINS, Georgina. Minha família é colorida. Ilustraçôes de Maria Eugênia. São Paulo: SM, 2005.

MEIRELES, Cecília. Problemas da literatura infantil. 4. ed. Rio de Janeiro: Nova Fronteira, 1984.

OLIVEIRA, Maria Anória de J. Negros personagens nas narrativas literárias infanto-juvenis brasileiras: 1979-1989. 2001. 182f. Dissertação (Mestrado em Educação) - Programa de Pós-Graduação em Educação 
e Contemporaneidade, Departamento de Educação da Universidade do Estado da Bahia, Salvador.

PAULINAS: a comunicação a serviço da vida. São Paulo: S2

Comunicação Integrada, 1997-2010. Disponível em: <http://www. paulinas.org.br/home/home.aspx..>. Acesso em: 17 nov. 2009.

SILVA, Ana Célia da. Desconstruindo a discriminação do negro no livro didático. Salvador: EDUFBA, 2001.

. A desconstrução da discriminação no livro didático. In:

BRASIL. Ministério da Educação, Secretaria de Educação Continuada, Alfabetização e Diversidade. Superando o racismo na escola. 2.ed. Brasília, 2005.

SOUZA, Francisca Maria do Nascimento. Linguagens escolares e reprodução do preconceito. In: BRASIL. Ministério da Educação, Secretaria de Educação Continuada, Alfabetização e Diversidade. Educação anti-racista: caminhos abertos pela Lei Federal no 10.639/03. Brasília, 2005.

SUPERMERCADO Moderno. São Paulo: Grupo Lund, 2010.

VASQUES, Marciano. Rufina. Ilustrações de Osório Garcia. Juiz de Fora, MG: Franco, 2004. 
Black boys and girls in brazilian children's

literature: (un)veiling prejudices

\section{Abstract}

This article conducts a reading of literature for children's reception and analyzes how the texts present ethnicracial issues, based on a characterization of personalities, in this case girls and boys. The books chosen for analysis are Menina bonita do laço de fita, by Ana Maria Machado; Conceição de Vila Rica, by Joaquim Borges; Rufina, by Marciano Vasques; Minha familia é colorida, by Georgina Martins; and Minhas Contas, by Luiz Antonio. In addition to presenting black children as characters, the narratives chosen are related by the fact that these characters are found in contemporary spaces and presented in their daily activities. With this reflection, the paper discusses subtle references in the titles, which, even if well intentioned, are biased and reveal prejudices, whether in the illustrations, the characterization of the characters; or in titles that achieve the alterity.

Key words: Literature for children and youth. Racism in literature.
Filles et garçons noirs dans la littérature infantile brésilienne: (dé)voilant les préjugés

\section{Résumé}

Ce texte est centré sur la lecture de livres de littérature infantile et sur la reception des enfants à propos des questions éthnicoraciales à partir de la caractérisation des personnages, en l'occurrence les filles et les garçons. Ce sont les livres choisis pour cet analyse: Menina bonita do laço de fita, d'Ana Maria Machado; Conceição de Vila Rica de Joaquim Borges; Rufina de Marciano Vasques; Minha família é colorida de Georgina Martins et Minhas Contas de Luiz Antonio. Au-delà de met en scène des enfants noirs, les histoires choisies s'entrelacent car ces personnages se retrouvent dans des espaces contemporains, représentés dans leurs activités quotidiennes. À partir de cette réflexion, on envisage montrer des lapsus présents dans les titres, lesquels, mêmes s'ils sont bien intentionnés, manifestent un biais discriminatoire - (ré)vélant des préjugés, soit dans les illustrations, soit dans la caractérisation des personnages, $y$ compris les titres qui attendent l'altérité en dévoilant les préjugés.

Mots-Clés : Littérature infantile Racisme dans la littérature.

\section{Eliane Debus}

E-mail: elianedebus@hotmail.com 